\title{
Análise Praxiológica do Desenvolvimento Urbano de Grandes Cidades Brasileiras
}

Norton Caetano ${ }^{I}$ (1) 0000-0002-6748-3305

Universidade Federal de Rondônia - UNIR - Porto Velho - Rondônia - Brasil

Idone Bringhenti ${ }^{I I}$ (1) 0000-0002-7177-5861

Universidade Federal de Rondônia - UNIR - Porto Velho - Rondônia - Brasil

Edwards Miranda ${ }^{I I I}$ (1) 0000-0002-0142-7976

Universidade Federal de Rondônia - UNIR - Porto Velho - Rondônia - Brasil

Leroy Grumble ${ }^{I V}$ (1) 0000-0003-1737-7229

NetunoDev - Rolim de Maura - Rondônia - Brasil

Evanice Almeida Pinto ${ }^{V}$ (1) 0000-0002-6467-6929

Universidade Federal de Rondônia - UNIR - Porto Velho - Rondônia - Brasil

Resumo: O presente artigo analisa o desenvolvimento urbano de grandes cidades brasileiras segundo uma lógica praxiológica, em que a ação humana é tomada como o principal fator de expansão e considerada uma reação à dinâmica de incentivos econômicos que atuam regionalmente ao longo do tempo. Fatores culturais, geográficos e a própria intervenção estatal condicionam a expansão urbana, sendo que analisar a interação entre elas permite compreender a dinâmica do desenvolvimento urbano. Grandes cidades brasileiras apresentam uma expansão do tipo periférica, na qual os recursos auferidos pelo cidadão comum só permitem a aquisição de imóveis localizados distantes da extensa e intrincada burocracia imposta pelos Planos Diretores municipais, que escasseiam e encarecem artificialmente as áreas onde a fiscalização alcança, induzindo as periferias à anarquia. Burocratas e políticos não estão sujeitos a incentivos de mercado, o que resulta em ausência de planejamento estratégico e má alocação de recursos humanos e financeiros.

Palavras-chave: Expansão urbana, planejamento urbano, plano diretor, eixo estruturante, cidade.

\footnotetext{
I Professor do Departamento de Matemática - UNIR (Universidade Federal de Rondônia). Engenheiro Civil, Doutor em Geociências e Meio Ambiente. E-mail: norton@unir.br.

II Professor do Departamento de Economia - UNIR (Universidade Federal de Rondônia). Engenheiro Civil, Doutor em Engenharia Urbana. E-mail: idone.br@gmail.com.

III Acadêmico de Economia (UNIR). $3^{\circ}$ Sargento Aeronáutica. E-mail: edwards.miranda123@gmail.com.

Iv Programador e Consultor na NetunoDev. E-mail: leroy.grumble@gmail.com.

v Acadêmica de Física (UNIR). E-mail: evanicebispoalmeida@outlook.com.
} 


\title{
Praxiological Analysis of the Urban Development in Brazilian Great Cities
}

\begin{abstract}
This article analyzes the urban development applied in great Brazilian cities according to a praxiological logic, in which human action is the main factor of expansion and a reaction against the economic and political incentives in a given region. Cultural, geographical, and beadledom factors condition urban expansion, and analyzing their interaction allows us to understand the dynamics behind it. Great Brazilian cities showed peripheral expansion, in which ordinary citizens can only buy houses away from the center of cities; Impositions of the Master Plan law turns properties artificially to more expensive, leading the periphery to anarchism. Bureaucrats and politicians are not affected by market incentives that induce a lack of strategic planning and inadequate human and financial resources allocation.
\end{abstract}

Keywords: Urban expansion, urban planning, Master Plan, structuring axis, city.

\section{Estudio praxiológico del desarrollo urbano de grandes ciudades brasileñas}

Resumen: Este ensayo analiza el desarrollo urbano de grandes ciudades brasileñas de acuerdo con una lógica praxiológica, por la cual se comprende la acción humana como principal factor de expansión y como reacción a la dinámica de incentivos económicos que actúan regionalmente a lo largo del tiempo. Factores culturales, geográficos y la propia intervención estatal son condicionantes en la expansión urbana, cuyo análisis de interacción permite una comprensión de la dinámica del desarrollo urbano. Grandes ciudades brasileñas presentan una expansión tipo periférica, adonde los recursos adquiridos por los ciudadanos comunes solamente permiten a adquisición de inmuebles localizados distantes de la extensa y intrincada burocracia impuesta por los Planos Directores de la municipalidad, que encarecen artificialmente las áreas adonde llega la vigilancia y inducen las periferias a la anarquía. Burócratas y políticos no están sujetos a incentivos de mercado, que llevan a ausencia de planeamiento estratégico y mala asignación de recursos humanos y financieros.

Palabras clave: expansión urbana, planeamiento urbano, plano director, eje estructurante, ciudad. 


\section{Introdução}

Para abordar o desenvolvimento urbano no Brasil, será utilizado o método analítico, apresentando ideias e argumentos que devem resistir à discussão lógica, dentro do pressuposto da busca pela verdade. O paradigma utilizado é o do direito natural ou jusnaturalismo (BASTIAT, 1850), que garante liberdade individual de ação e que gera eficiência na alocação de recursos, como apresentado por Mill (1848), Hayek (1985; 1997) e Mises (1949).

As capitais estaduais e outras grandes cidades brasileiras já nascem enfrentando, além das dificuldades naturais e logísticas, os entraves burocráticos para sua demarcação. De maneira geral, as grandes cidades brasileiras apresentam um período de leve crescimento desde sua inauguração até uma fase de forte crescimento, ligado à industrialização e/ou ao êxodo rural do século XX, mais nítido quanto mais antigo for o agrupamento urbano, apresentando a partir daí os famosos ciclos de crescimento/estagnação, neste caso nem sempre diretamente oriundos de práticas keynesianas, apesar de consequência dessas, mas da disponibilidade de oportunidades de trabalho, seja na indústria, serviços ou no Estado.

Apesar disso, muitas das grandes cidades brasileiras experimentam um fluxo inverso nas últimas décadas, com a expansão de cidades vizinhas, que vem a formar regiões metropolitanas. Os fluxos urbanos agora são descentralizados em vários núcleos que, no limite, se definem em bairros. Assim se forma um aglomerado gigante se visto de cima, mas com interações concentradas na maior parte dos casos. O grande aglomerado urbano se sustenta pela concentração de mentes e serviços, assim viabilizando atividades cada vez mais complexas e favorecendo um ambiente de circulação de recursos e ideias.

Ainda há no Brasil grandes cidades que dependem do funcionalismo público para se viabilizar, especialmente as capitais: Brasília, Boa Vista, Macapá, Rio Branco e Palmas, enquanto as grandes cidades do interior se viabilizam pela atividade privada, como Campinas/SP, Vilhena/ RO, Rondonópolis/MT, Campina Grande/PB, Passo Fundo/RS, Maringá/PR, entre outras.

Com o objetivo de gerenciar e planejar o desenvolvimento das grandes cidades brasileiras e como parte da política urbana brasileira foi instituído o Plano Diretor pela Lei $n^{\circ} 10.257$, de 10 de julho de 2001, cujo texto é centrado na ação governamental e carregado de sofismos, de termos vagos que permitem interpretação diversa e de direitos por decreto.

Na prática, quem elabora o Plano Diretor são os agentes técnicos das prefeituras locais que, via de regra solicitam apoio do IBAM - Instituto Brasileiro de Administração Municipal e também há casos de contratação de empresa especializada na área. O problema é que, quanto mais Estado, maior a burocracia e mais os incentivos são os oriundos da política e suas conveniências, respondendo menos a incentivos de mercado.

O fato é que décadas antes de haver uma exigência legal, muitas das grandes cidades se preocupavam com o planejamento da expansão urbana, encomendando estudos de empresas especializadas ou dispondo de seu próprio corpo técnico para tal. A grande pergunta para o tema é: o que deu errado?

Tentando compreender esse fenômeno Bertaud (2017) encontra uma resposta no planejamento central baseado em ideologias, no que chama de utopia, ou cidade idealizada. 


\section{Diagnóstico}

\subsection{Dos Ciclos}

A Figura 1 (abaixo) apresenta um esquema da expansão urbana observável nas grandes cidades brasileiras ao longo do tempo, a qual seguem ciclos econômicos de expansão e recessão, fruto de práticas de aumento da base monetária e endividamento por parte do governo, legando cada vez mais informalidade, desindustrialização, desemprego e pobreza nas áreas urbanas.

A partir do momento em que uma cidade se torna grande, se iniciam ciclos de maior e menor crescimento econômico e populacional (EVANS et. al, 1998), que se associam aos ciclos econômicos, como descrito por Hayek (1933). As cidades crescem devido inicialmente ao êxodo rural e posteriormente por atrair pessoas da região, de outras regiões do país e mesmo de outros países.

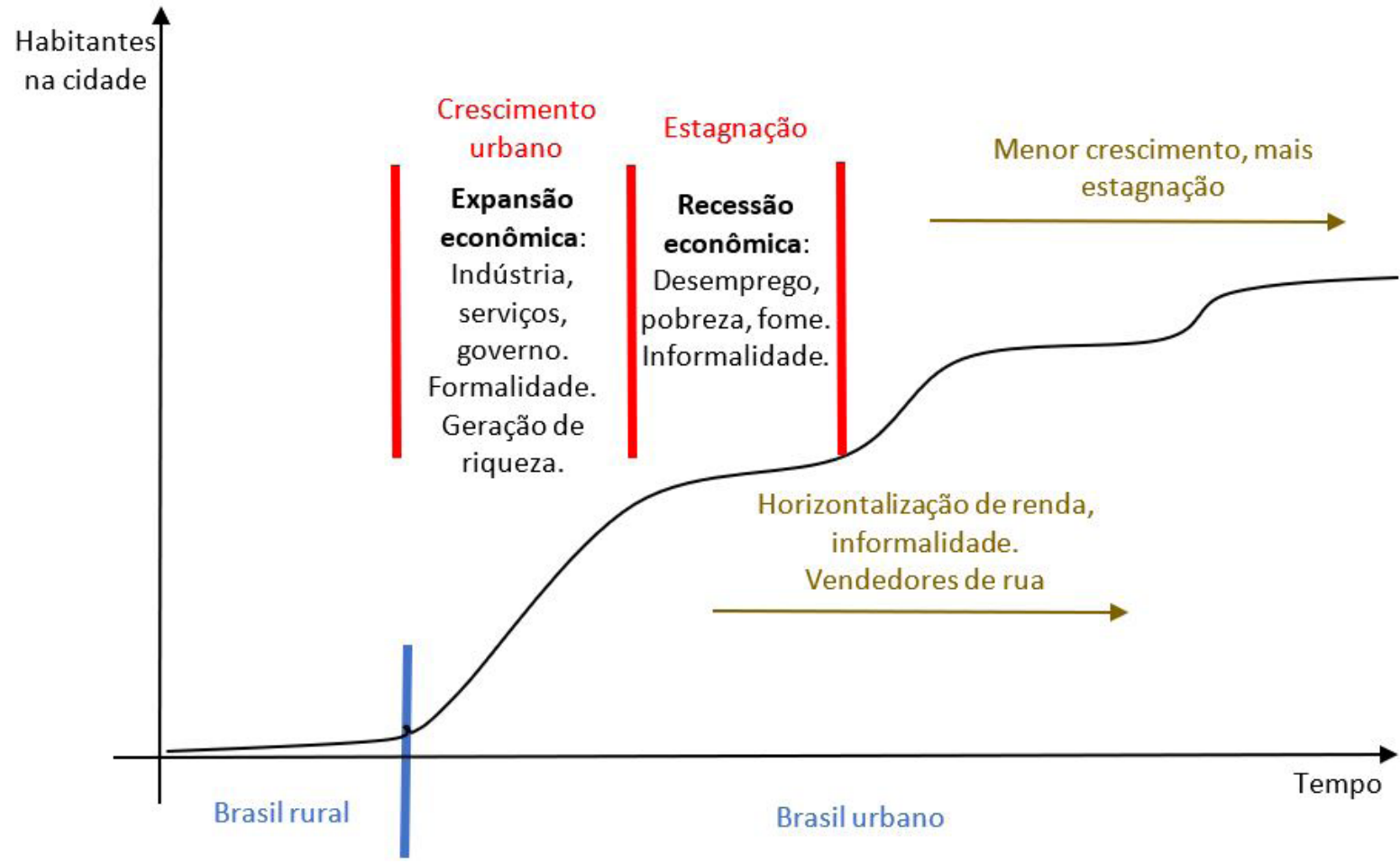

Figura 1. Esquema de expansão urbana segundo ciclos econômicos.

Expansão das atividades industriais, comerciais, maior demanda por serviços e mesmo aumento de vagas no funcionalismo público trazem pessoas e suas famílias para a cidade, mas coincidem com deterioração da liquidez (endividamento), até o pico da expansão associado à escassez da liquidez. A partir de então há uma contração na economia associada a liquidação de ativos (a valores mais realistas), até a fase de recuperação econômica, que se trata de aumento da poupança e recapitalização das pessoas, empresas e governo. O ciclo se reinicia novamente com expansão econômica. 
As pessoas atraídas para um dado polo urbano no período da expansão econômica, apresentam em geral uma tendência a não regressar para seu local de origem quando da recessão econômica, gerando não uma diminuição da população urbana, mas apenas um crescimento menor ou estagnação.

Analisando os incentivos para a permanência das pessoas/famílias na cidade, pode-se elencar: (1) a memória de bem-estar do período de expansão, (2) a esperança de retorno aos bons tempos, (3) a infraestrutura disponível (educação para os filhos, saúde, mantimentos, abastecimento, serviços urbanos etc.), (4) a rede de relações (vizinhos, amizades, contatos etc.), (5) além da própria dificuldade da mudança (custos, tempo, esforço etc.) e (6) das incertezas envolvidas com outro lugar. Para aquelas que vieram via êxodo rural geralmente inexiste a possibilidade de retorno, dado que venderam suas propriedades, apostando tudo o que tinham em uma vida urbana.

\subsection{Da Infraestrutura}

Para viabilizar uma grande cidade há necessidade de garantir toda a sorte de infraestrutura (água, energia, lixo, acessos, comunicações, suprimentos etc.), além de muitas possibilidades de entrada e saída, seja de pessoas ou de bens. Então essas vias de comunicação podem ser naturais como rios, ou construídas como ferrovias e rodovias.

Por tal razão, é que as cidades brasileiras mais antigas começaram como vilas e pequenos agrupamentos à beira de corpos d'água, depois à beira de estradas de ferro e mais recentemente margeando rodovias. Em alguns casos o primeiro condicionou todos os outros, como nas cidades ao longo do vale do rio Paraíba (São José dos Campos/SP até Volta Redonda/RJ), em outros o corpo d'água era o próprio oceano.

De qualquer modo, toda a infraestrutura a ser oferecida em uma área urbana depende primordialmente de grandes vias de acesso. Segundo Zmitrowicz e Borghetti (2009) a viabilidade de uma grande cidade depende de grandes eixos estruturantes, que normalmente são as grandes avenidas que permitem a expansão de subsistemas urbanos (ZMITROWICZ; NETO, 1997) como transporte, energia, comunicação e internet, água, esgoto, drenagem, lixo etc.

Então toda grande cidade tem suas avenidas principais que, quando planejadas, são de tendência linear e plana, contínuas, interconectadas, largas e ainda com possibilidade de alargamento ou de implantação de vias marginais. Quanto mais vias nesse molde, mais agilidade no deslocamento, menor custo para implantação e oferecimento dos serviços, menos externalidades (acidentes, engarrafamentos etc), mais possibilidades de acesso a trabalho e lazer, maior comunicação, menor valor de seguro e maior previsibilidade (CTAM, 2020). Para mensurar a eficiência no deslocamento urbano o IPEA desenvolveu o projeto "Acesso a Oportunidades" disponível em https://www.ipea.gov.br/acessooportunidades/.

Onde o modelo de grandes eixos estruturantes não se materializa, abundam vias descontínuas, estreitas e sinuosas, que dificultam o deslocamento, a localização, a instalação da infraestrutura (subsistemas urbanos), o oferecimento de serviços etc. Há casos em que um planejamento inicial se estende de maneira informal, com o prolongamento de grandes avenidas, seja num modelo quadriculado (Porto Velho) ou radial (Boa Vista). No entanto, as avenidas 
perpendiculares (de cruzamento) que dariam suporte a essa expansão, invariavelmente não seguem o padrão e acabam por limitar o estabelecimento de eixos estruturantes.

Outro fato é que não bastam grandes avenidas para suportar uma grande cidade. Os casos de São Paulo e Rio de Janeiro mostram que avenidas cada vez maiores seriam necessárias. Soluções integradas, como observado por Ling (2017), devem ser desenvolvidas.

Com relação ao desenho urbano, o mais comum é o de crescimento espontâneo (JACOBS, 1961), que após consolidado, é entrecortado por grandes avenidas, muitas vezes via desapropriação, na tentativa de proporcionar eixos estruturantes. A execução de anéis viários nas grandes cidades, especialmente nas mais antigas (São Paulo, São José dos Campos e Campinas), foi uma tentativa de adaptar um modelo de anéis concêntricos, como também tentado em Londres. Em cidades litorâneas, entrecortada por canais e espremidas entre o mar e a serra, se tentou grandes avenidas, elevados e viadutos lineares costeiros e marginais às montanhas (Florianópolis, Rio de Janeiro, Vitória e Recife). Raros foram os casos em que houve planejamento urbano recente, como em Palmas (modelo quadriculado).

O modelo de expansão urbana que ganha força nas últimas décadas são os condomínios privados. Como anexos à área urbana das grandes cidades, essas estruturas podem funcionar praticamente independente delas, fornecendo aos residentes todos os serviços urbanos: água, esgoto, energia, lixo, comunicação, vias, segurança, lazer etc. Nesse modelo de desenvolvimento, a função do planejamento urbano municipal muda completamente, cabendo ao poder público a definição dos grandes eixos estruturantes, ao longo do qual se desenvolverão as atividades em áreas privadas. Então o poder público muda o nível de atuação e passa a ser planejador da estratégia global.

\subsection{Do Plano Diretor}

O que se chama de planejamento urbano municipal se dá no âmbito do Plano Diretor, que Brasil afora se materializa em um emaranhado de regras, enumeradas em artigos, parágrafos e incisos que são, como a própria Lei Federal que a originou: sofismos, termos vagos, direitos positivos e planejamento central. Mas ainda pior que a Lei originária, o Plano Diretor se radicou pela ânsia de legislar sobre absolutamente tudo, inclusive no que tange à propriedade privada e, ao fazer isso, perdeu qualquer caráter estratégico.

Planos Diretores ao longo do tempo foram assumindo uma função, quando muito, cartorária, apenas registrando os agrupamentos urbanos que foram surgindo e os incorporando à área urbana formal da cidade, sempre com a visão de tentar conter a expansão urbana desordenada, via fiscalização e coerção.

Por outro lado, foram continuamente estabelecendo e pormenorizando regras de construção e urbanização, que dificultariam qualquer iniciativa de formalização. Mais burocracia, mais especificações, limitações, multas, taxas e coeficientes, legislando cada vez mais sobre pormenores, importando-se com cul-de-sac e olvidando-se do planejamento macro, das grandes questões urbanas, dos grandes eixos estruturantes. 
A Figura 2 pretende exprimir em um gráfico cartesiano a relação de incentivos entre burocratização/fiscalização impostas pelos planos diretores e o modelo de ocupação urbana (ERDMANN et. al, 2019). Observa-se que quando há pouca burocracia, praticamente não há informalidade, mas a partir de um ponto relacionado a quantidade e complexidade desse sistema, há uma explosão de ocupações informais que atinge a base da pirâmide social, são os mais pobres que já não tem mais condições de cumprir com as exigências legais. A partir daí cada aumento da burocracia e das exigências vai levando uma taxa cada vez menor de cidadãos à informalidade, subindo na pirâmide social, até um ponto que já há tanta gente na informalidade que qualquer aumento na burocracia pouco impacta a decisão por parte dos cidadãos, já não há mais escolha.

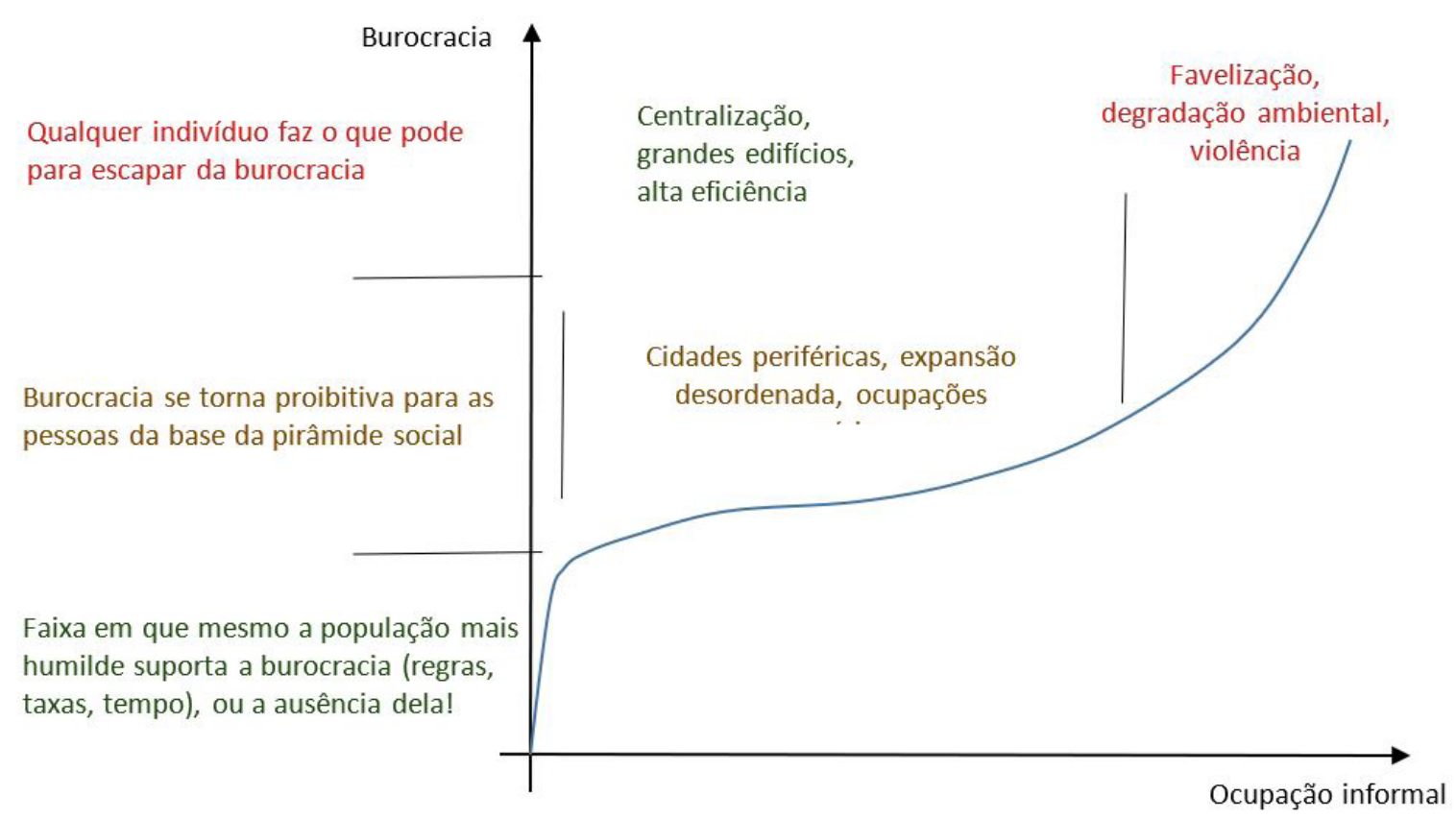

Figura 2. Relação entre burocratização e informalidade na ocupação urbana.

Da mesma escola de urbanismo de Brasília/DF, os Planos Diretores legislam sobre o que se permite e não se permite em cada parcela da cidade e buscam estabelecer um zoneamento, que Ikeda (2015) trata como uma política excludente por definição. Se é que essa visão funciona na Brasília/DF de avenidas gigantes, em que o rígido modelo concebido não permite adaptações pelas demandas do mercado (BERTAUD, 2010), em qualquer cidade real sugere não funcionar.

Parece normal que atividades que produzam ruído, vibrações, gases ou calor excessivo não estejam geograficamente (fluxos de espaço e economia, como observado por Santos (1978)) associadas a residências, no entanto, toda a gama de serviços o está! Cidades como Houston simplesmente não possuem zoneamento (GREY; MCBIRNEY, 2020), lá a livre organização dos indivíduos produziu o metro quadrado mais barato do Texas/EUA, privilegiando condomínios residenciais. 
O estudo pioneiro sobre o assunto é o de Siegan (1972) que, comparando cidades no Texas, observa incentivos perversos em toda a tentativa de formalização da ocupação urbana, levando a tensões sociais, corrupção, escassez artificial e encarecimento da construção, como também observado por Glaeser e Gyourko (2003).

Na tentativa de promover o tão sonhado adensamento urbano, os burocratas das grandes cidades se empenharam em elaborar Planos Diretores, que criavam limites para a área urbana formal. Elaboraram termos sofistas como eficiência urbana e alegaram aumento de custos dos sistemas urbanos (energia, iluminação, água, esgoto, lixo etc.) e pressão sobre o poder público, mas sem considerar aspectos do adensamento como analisado por Angel et. al (2021). O caso é que, ao passo que desejavam uma ocupação dos terrenos vazios, proibindo a ocupação fora de limites físicos preestabelecidos, tornavam proibitiva a ocupação dessas mesmas áreas pelo excesso de regulação, fiscalização, imposição de multas, impostos etc., que são sempre limitantes à livre iniciativa e/ou organização dos indivíduos.

De fato, essas regulações incentivaram o surgimento de dois Brasis (LAMBERT, 1967), que incrivelmente coexistem praticamente lado a lado nas grandes cidades brasileiras:

- $1^{\circ}$ Classe: formal, de distintos cidadãos, fino, requintado, progressista e empático, situado ao redor de centros e zonas valorizadas, alvo da fiscalização, cheio de regulações, com fiscais averiguando os famosos quartos de empregada, tamanho de janelas, altura de tomadas etc., aos que se somaram os fiscais da segurança do trabalho que verificam tapumes, cor da sinalização, mapas de risco, altura de escada etc., aos que se somaram os fiscais da acessibilidade que verificam existência e inclinação de rampas, mais altura de tomadas, faixas táteis, e toda uma sorte de quesitos arbitrários e subjetivos, mas obrigatórios. A preocupação da $1^{\circ}$ classe é com grandes temas mundiais: fome na África, camada de ozônio e aquecimento global.

- $2^{\circ}$ Classe: informal, de cidadãos lembrados apenas em tempos de eleições, depauperado, famélico, enlameado/empoeirado, feio, sobrevivente e dependente, situado nas periferias e áreas invadidas, longe da fiscalização, sem regulações, sem Estado. A preocupação da $2^{\circ}$ classe é pela sobrevivência, por mais um dia!

Portanto a ocupação informal de áreas, normalmente periféricas, aqui denominada de invasão, é consequência indireta da ação Estatal pelo Plano Diretor, como também identificado por Silva et. al (2011).

Da dinâmica da invasão, observa-se que após a consolidação da ocupação, normalmente quando se dividem os lotes, cada qual com seu barraco e, se definem as vias, iniciam-se as melhorias como ligação de energia elétrica, construções em alvenaria ou madeira de melhor qualidade, pavimentação da via com cascalho, denominação da via e numeração dos lotes, até o reconhecimento pelo poder público quando se adquire o direito a solicitar um título de propriedade e pagar IPTU.

Nessas invasões, há pouco incentivo para investimento, haja visto que o reconhecimento de propriedade é dado basicamente pela posse do imóvel diante dos vizinhos. Não há reconhecimento do poder público, que inclusive se torna uma ameaça à ocupação e escasseia 
a oferta de lotes. Portanto é comum encontrar loteamentos clandestinos com aspecto de favela. Esse ambiente, por vezes insalubre, atrai políticos que prometem "resolver o problema", portanto há também incentivos aos próprios políticos que haja invasões, que elas não sejam reconhecidas e que sejam precárias.

A depender das ações dos moradores das invasões, o processo de ocupação pode gerar desde loteamentos viáveis até favelas extremamente precárias. Na expansão por invasão cada lote capta água por poço (Manaus, Porto Velho) ou desvia do sistema público (Rio de Janeiro), destina esgoto em fossas (normalmente negras) ou diretamente em corpos d'água in natura e, incinera lixo. Mas enfim, podem ser autossuficientes na implantação, divisão dos lotes, determinação das vias, pavimentação e infraestrutura de serviços, sem necessitar nenhuma intervenção Estatal para tanto.

No entanto, ao longo das gerações essas invasões também não se mostram satisfatórias, pois com o crescimento da família e a maioridade dos filhos(as), novas famílias vão se formando, o que provoca uma pressão por mais invasões, já que os lotes invadidos são pequenos e via de regra não comportam subdivisões. Fato análogo ocorre em Florianópolis com os remanescentes dos açorianos que informalmente ocupam lotes morro acima para comportar as famílias das novas gerações, já que a ocupação urbana formal na ilha da capital catarinense é extremamente burocrática, limitadora e, portanto, caríssima! Vale notar que praticamente os mesmos açorianos produziram um urbanismo totalmente diferente em Porto Alegre, o que leva a concluir que o ambiente condiciona a forma de ocupação e a própria cultura, então estamos falando de geopolítica, cujas implicações serão abordadas no item

\subsection{Limitações Físicas}

O Plano Diretor deveria ser uma obra de planejamento. Tratando da descentralização da informação no planejamento, Minkler (1993) pensa cada indivíduo como um trabalhador consciente, que possui mais informação que seu próprio chefe sobre os problemas do dia a dia, situação que força soluções do tipo de baixo para cima, diferente do modelo hierarquizado, onde a chefia dispõe de informações mais complexas e que a ela cabe decidir. Nesse ambiente, onde cidadãos podem conhecer e burocratas devem conhecer, decisões hierarquizadas tendem a ser mais ineficientes. É o que acontece com o planejamento urbano, onde políticos e burocratas impõem sua visão de mundo de maneira hierárquica sobre a cidade, obrigando os indivíduos a viver conforme regras que lhe são estranhas. Portanto é o indivíduo, ou a família, em sua propriedade, em contato com seus vizinhos, que dispõe de informações mais relevantes sobre sua própria realidade cotidiana e pode tomar as decisões de maneira mais eficiente.

No entanto, só o conhecimento disperso na sociedade parece não resolver tudo. Becker (2002) ao analisar o processo de tomada de decisão em ambientes organizacionais conclui que da informação descentralizada decorrem três problemas: excesso de nomenclaturas e subdivisões, excesso de diferentes estratégias para lidar com os mesmos problemas e, burocratização das decisões. Deveria haver então um mínimo de ordenamento para aumentar a eficiência (Figura 2).

Contudo, mesmo o Plano Diretor das grandes cidades brasileiras tendo um caráter centralizado, incorre nos mesmos problemas da informação dispersa apontada por Becker 
(2002): listagem de chavões e excessiva criação de terminologias, excesso na subdivisão de zonas urbanas e um produto final extremamente burocratizado.

E, por que o Plano Diretor no Brasil se transformou nisso? Em parte, já vimos a resposta: cidade idealizada, concebida para não atender às demandas de mercado e sujeita a incentivos trocados. Vejamos outras limitações.

\section{Limitações}

\subsection{Burocráticas}

Dentro da prática política, tendo estabelecido o Plano Diretor, os políticos passam a negociar emendas à lei com meta-capitalistas ávidos por empreendimentos sem concorrência! A prática política cria monopólios/oligopólios na construção de prédios e condomínios em regiões especiais dentro do zoneamento urbano. Há casos de ruas que se transformam em terrenos, zonas que são modificadas nos mapas e nas leis, artigos e parágrafos de lei que são suprimidos, limites verticais e taxas de ocupação que podem ser ultrapassados, enfim toda essa burocracia é um mar a ser desbravado para os amigos do rei endinheirados, mas uma limitação intransponível para o pequeno e médio empreendedor.

O ambiente da política e do funcionalismo público na democracia se efetiva pela burocracia. Ao longo do tempo, tanto leis positivadas quanto normas, procedimentos e regulações internas de órgãos públicos cresceram livremente, alimentando-se da ascensão em tamanho e complexidade do Estado, gerando um ambiente antinatural e, portanto, anti-humano, onde funcionários públicos são inundados por regras, modelos e sistemas de ação e controle que, na prática fazem limitar a ação empreendedora e não bastam para conter a corrupção.

Esses funcionários públicos vivem um dilema: Se agem e acertam nada lhes acrescenta, se agem e não acertam podem ser responsabilizados. Se não agem, o que estão fazendo ali? Acaba gerando frustração, melancolia, inveja, disputas internas por mediocridades etc. Empreendedores e prestadores de serviços também sofrem com esse sistema, como na operação das agências nacionais (águas, aviação civil, comunicação, mineração etc.), onde cada novo Superintendente, indicado por um político, tem o incentivo de criar mais regras, seja para fazer a coisa do seu jeito, beneficiar aos seus ou mostrar serviço. Decorre disso um emaranhado de regras, exceções de regras e regras que definem as exceções das regras, como mostrado por Leôncio (2014).

No caso do planejamento urbano, a sanha legisladora delimita zonas urbanas, lista o que se permite em cada uma delas, cria coeficientes, estipula limites, determina materiais de construção, exige dimensões diversas. É o Leviatã de Hobbes crescendo e adentrando em cada vez mais aspectos da vida privada, criando um ambiente artificial e, portanto, ineficiente (IKEDA, 2016).

Após criar todo esse emaranhado positivo de leis, normas, regras, portarias e dentro delas uma infinidade de exigências, o poder público conta com a colaboração das pessoas, seja por concordância, ideal ou coerção e, com a atuação de fiscais que supostamente farão 
prosperar tal legislação. $\mathrm{O}$ fato de leis positivadas não obedecerem a ordem natural do mundo e/ou do ser humano, cria anacronismos que as pessoas ao longo do tempo tendam a violar. Então se configura um sistema em que algumas pessoas (as vezes não são técnicos ou não há embasamento científico, em outras é pura arbitragem) decidem sobre regras, zonas e métricas de urbanismo idealizando um espaço urbano difícil de se realizar neste mundo.

Como consequência da burocracia surgem monopólios/oligopólios artificiais na implantação de infraestrutura e no oferecimento de serviços urbanos formais. Da análise da organização formal e informal da sociedade na área urbana se observa que:

I. É somente a burocracia Estatal que pode atestar a propriedade de um lote, inclusive com serviços e taxas duplicadas de escritura e registro de escritura. Ainda, o Estado reserva para si boa parte das áreas e há casos em que ainda trata a propriedade privada como aforamento, ou seja, um tipo de concessão estatal que data do Brasil Império. Enquanto informalmente as invasões são normalmente pacíficas e espontaneamente organizadas, há poucos litígios. É um caso de sucesso de livre organização e associação de indivíduos que dispensa qualquer interferência estatal, onde há legitimação natural da propriedade privada de maneira rápida e eficiente por meio dos contratos de compra e venda e reconhecimento da vizinhança.

II. O poder público é o único ente que pode executar ou manter vias, inclusive penalizando quem o fizer de maneira informal. Em todo o país há casos de multas por pavimentar a rua. Nas invasões as vias são demarcadas em comum acordo entre os participantes e o serviço de pavimentação é dividido entre eles, há casos de ajuda de políticos que, novamente têm interesse populista nesse tipo de organização. O problema é que as vias são de pequena dimensão e sem conexão com loteamentos vizinhos, que gera um ambiente ideal para bandidos, que usam a informalidade para se esconder e viabilizar seus crimes.

III. O abastecimento de água é atribuído a uma autarquia municipal ou concessão, que opera captação, tratamento, reserva e distribuição centralizados. Há perdas na distribuição (em torno de $40 \%$ no Brasil), abastecimento intermitente com o hidrômetro das residências girando pela passagem do ar preso na tubulação (várias cidades de Rondônia), tratamento insuficiente (Rio de Janeiro) ou captação insuficiente (semiárido nordestino). Já na informalidade o abastecimento é descentralizado, de baixa vazão e custo, normalmente com captação por poço cacimba próximo à rua, onde praticamente não há perda na distribuição, mas pode haver baixa qualidade da água.

IV. A coleta de esgotos também é atribuição de autarquia municipal ou concessão, que cobra o serviço junto com a fatura de água sem nem mesmo coletar os efluentes, há casos de ligação de águas pluviais na rede de esgoto e vice e versa. Nas invasões o esgoto é destinado para fossas sépticas ou negras no fundo dos lotes, o problema é que na época das chuvas poços de captação e fossas ficam no mesmo nível freático, gerando contaminação da água em lotes pequenos ou mal planejados. 
V. O fornecimento de energia elétrica é uma empresa ou concessão estatal; que assim que se abrem as vias, mesmo nas invasões, procede ligação de energia elétrica aos lotes. Se a empresa demora, as pessoas rapidamente fazem ligações clandestinas, que aumenta o risco de acidentes e gera um passivo para a própria empresa. Nesse caso os incentivos, de qualquer maneira, estão no sentido de prover o serviço, mas a um custo e eficiência impossíveis de serem medidos, dado o caráter monopolista.

VI. A coleta de lixo também é uma autarquia ou concessão estatal; que é remunerada por peso de resíduos sólidos e transportado para o aterro/lixão municipal, normalmente localizado em áreas de adversários políticos. Os aterros/lixões municipais, de caráter centralizado, são montanhas de resíduos, centros de poluição do ar, do solo e das águas superficiais e subterrâneas, futuras áreas comprometidas, foco de incêndios periódicos, criadouros de pestes de todo o tipo, aves e animais necrófagos etc. Enquanto nas invasões, de caráter descentralizado, o lixo orgânico fertiliza hortas e alimenta animais; metais, vidros e cartonados de valor econômico são enviados para reciclagem e, o resto é incinerado. O problema é o entulhamento de canais de drenagem por toda a sorte de lixo, restos de móveis e eletrodomésticos descartados.

VII. O setor de comunicação é o que assume algo parecido com concorrência. Apesar de pesada regulação e impostos há algumas empresas que oferecem o serviço. Há disponibilidade de sistemas de comunicação sem fio e, com a consolidação das áreas chega o serviço de fibra óptica. Os sistemas de comunicação sem fio não fazem distinção de formalidade e os com fio necessitam vias de grande porte para se viabilizar.

VIII.O serviço de entrega de encomendas é fortemente taxado e regulado, praticamente com monopólio dos Correios. Receber correspondências em uma invasão é impossível no início. Na medida que se consolidam as vias e a ocupação em si, a via recebe um nome, os lotes um número e, então, passa a funcionar esse serviço. Há novas empresas entrando no sistema com entrega descentralizada e desburocratizada.

IX. O serviço de justiça também é monopólio estatal. A lei é rigorosa para quem está na formalidade, mas condescendente para quem está na informalidade! Mesmo porque se for rigorosa exclui e marginaliza ainda mais o informal, mas então não deveria ser chamada justiça! Esse fato também atua como incentivo a políticos para defender os direitos dos pobres, gerando um ciclo pernicioso de populismo e submissão.

X. Para construir, o estamento burocrático assume que o cidadão necessita de licenças, cuja concessão é monopólio estatal. Obter um habite-se hoje em dia se tornou uma maratona na qual se percorre as secretarias de Urbanismo, Trânsito, Meio Ambiente, Fazenda (taxas), Corpo de Bombeiros e dependendo também Vigilância Sanitária. Para regularizar um poço de água, o procedimento é o de outorga. Cada secretaria dessas tem um rol de procedimentos, exigências, taxas, projetos, planos, estudos, que geram pendências, mais taxas, renovações, adequações ao porte etc., que são regulamentadas por portarias que mudam a cada novo Secretário/Superintendente, sem aviso prévio, nem justificativa. Ao longo do tempo só aumentam as exigências para liberação de 
qualquer empreendimento, mesmo uma simples residência. Nas invasões o cidadão é responsável por sua construção e sofrerá as penas ou colherá as benesses de suas ações, sendo somente esse fato objetivo o grande e único incentivo natural para construir.

XI. Quanto ao serviço de proteção (polícia), o uso da força também é monopólio estatal. Notadamente insuficiente (em termos materiais e humanos), burocratizado e com incentivos trocados, os agentes policiais lidam com a violência urbana. Os moradores de invasões recorrem às delegacias preexistentes, saturando o sistema público. Os que tem mais condição econômica adquirem equipamentos de segurança ou até contratam serviços privados (desde o vigilante de bicicleta até escolta armada). Dado o sentimento de insegurança, as pessoas buscam condomínios fechados. Nas invasões a lei é não deixar a casa só, ou seja, cabe ao indivíduo/família a proteção de sua propriedade privada.

XII. E, por fim, os serviços básicos de saúde são oferecidos em unidades públicas estatais. Há serviço privado, mas tão taxado, especialmente regulamentado e ostensivamente vigiado por fiscais que se torna caro e inviável para o cidadão comum. A saúde é mais um caso de excesso de regulamentação/fiscalização que gera monopólios/oligopólios artificiais, abrindo caminho para corrupção. Os moradores das invasões saturam o sistema público na sua proximidade, enquanto os que possuem algum recurso procuram clínicas populares, cada vez mais raras devido às exigências e fiscalização. A saúde privada tem que continuamente se adequar a cada vez mais exigências e normas, enquanto no sistema público os prédios estão ruindo, a falta de manutenção gera um ambiente insalubre, carecendo de materiais hospitalares e remédios. Além de incentivos mal alocados há o problema do custo marginal zero para quem utiliza o serviço público ou mesmo o privado por planos de saúde.

Na tentativa de substituir o Império da Burocracia atual por um Império da Técnica, poderia ser defendida uma legislação que garantisse um mínimo do ponto de vista técnico, que no limite poderia ser uma ABNT para desenvolvimento urbano, uma ideia de viés minarquista e positivista. O fato é que Robes (1651) já avisara do processo de agigantamento do Estado e de como esse ente tende a dominar tudo e todos. Assim, seria apenas uma questão de tempo para o Império da Técnica ruir e ser novamente dominado pelo Império da Burocracia. No entanto, abdicar da técnica gera prejuízo, desconforto, mal-estar, feiura e infelicidade.

Partindo de uma visão técnica, o traçado de eixos estruturantes pode ser eficiente dentro do planejamento central, desde que resolvesse os problemas de acordo com técnicas de pesquisa operacional (visão holística). Infelizmente, como observou Friedman (2004), o Poder Público não responde a incentivos de mercado voltados à eficiência e aos cidadãos. O Poder Público, com seus políticos e burocratas, tem pouco pudor com recursos que não lhes pertencem e que serão destinados a outrem; não respondem ou não são punidos por seus erros, aliás podem inclusive se beneficiar deles. Além disso, políticos estão sujeitos a grupos de pressão, como mostra Grey (2021), mais uma face tirânica da democracia.

O planejamento baseado em técnica, especialmente das grandes vias, para que sejam largas, retilíneas, interconectadas e contínuas, garante bem-estar e desenvolvimento a todos os 
usuários, sejam moradores ou transeuntes. Assim, as vias têm um caráter multiusuário, nãorival e não-excludente, normalmente se diria público, que difere do caráter de uma residência ou até de condomínios, onde os afetados são apenas seus moradores. Portanto, questões urbanísticas, especialmente os grandes eixos estruturantes, têm forte apelo social enquanto que residências/condomínios tem apelo individual. No entanto, legar o planejamento de eixos estruturantes ao poder público não tem resolvido a questão.

Empreendedores individuais que se mobilizem entre si tem incentivos corretos para abrir e manter vias, já que seriam limitados ou beneficiados por elas, a exemplo do que ocorreu com as ferrovias nos EUA (KOLKO, 1965). Em condomínios fechados o empreendedor também responde a incentivos corretos para planejar vias, sendo punido ou beneficiado por suas ações e assim, as projetando conforme a finalidade do empreendimento.

Condomínios privados são as ocupações urbanas mais livres e, não por acaso, de sucesso no Brasil. Há casos em que o empreendedor construiu acessos até avenidas preexistentes, fornecendo vias pavimentadas, água (captação, tratamento e distribuição), esgoto (coleta, tratamento e destinação), lixo (coleta, separação e destinação), rede elétrica, segurança interna, rede de fibra óptica, áreas verdes, espaços comunitários e de lazer etc.

Mas também há casos de fracasso, como nos casos informais de alta valorização, que gera grande especulação imobiliária, podendo culminar em adensamento, iniciando um processo de verticalização tal que acaba se descolando da viabilidade técnica.

O gráfico da Figura 3 apresenta de maneira esquemática a relação entre tamanho do lote e o valor da área (especulação imobiliária, que obedece a lei de demanda por ocupação), cujo comportamento, no limite, leva a favelização (degradação do ambiente, construções de baixa qualidade técnica, invasão de vias etc.).

O esquema apresentado na Figura 3 é resultado da burocratização do sistema, pois quando há valorização natural da terra por demanda, incorporadoras tem incentivos para construir prédios, mantendo lotes maiores, beleza e salubridade.

O tamanho mínimo do lote deve considerar aspectos climáticos como umidade, temperatura, ventilação e iluminação, acessos, destinação de uso, jardinagem, animais entre outros. Portanto não há possibilidade de se definir um tamanho mínimo para os lotes. Cada empreendedor/ planejador/especulador/incorporador, respondendo a incentivos de mercado, tem a melhor chance para projetar o tamanho ideal para seu caso.

O fenômeno da demanda por ocupação é também influenciado pela proximidade a polos naturais como praias, recantos turísticos etc., ou artificiais como shopping centers, estações de transporte, praças, portos, universidades etc.

Do comportamento linear mostrado, na Figura 3, pode-se concluir que a subdivisão extrema em lotes cada vez menores gera ambientes precários e insalubres, mas são estes os únicos ao alcance da população mais carente. Na outra ponta, estão prédios e condomínios privados de alto padrão em espaços amplos e bem planejados. 


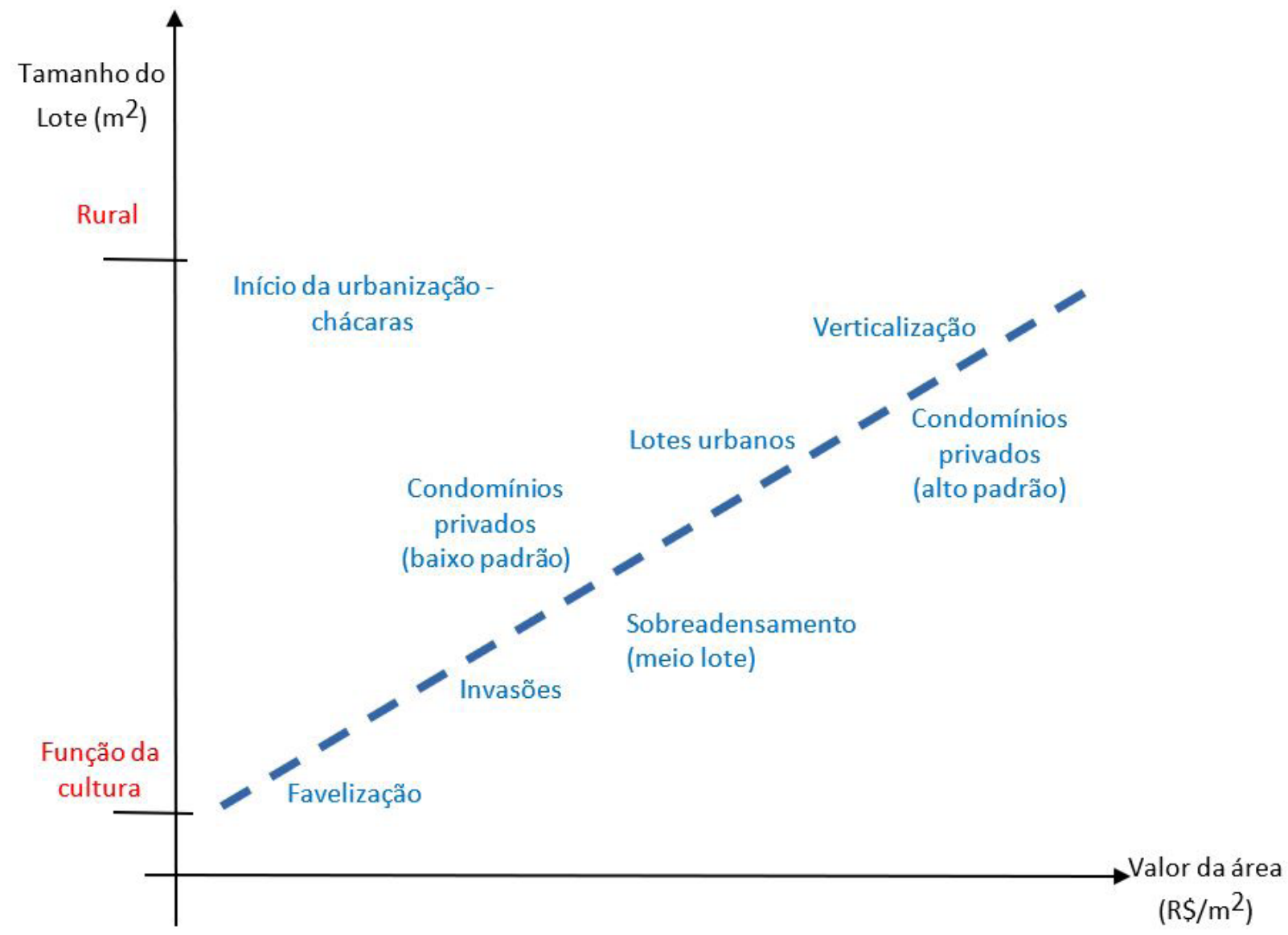

Figura 3. Relação entre Tamanho do Lote e Especulação Imobiliária.

Ainda com relação à demanda por ocupação, observa-se que, nas áreas centrais das grandes cidades brasileiras, há uma diminuição do interesse ao longo do tempo, associada também ao crescimento de restrições por parte da burocracia, resultando em desvalorização das zonas centrais. No entanto, o valor desses imóveis nem sempre caem na mesma proporção.

Há um forte fator cultural no brasileiro médio com relação ao centro, mas que tende a diminuir com o tempo. Para famílias tradicionais, os imóveis têm um valor simbólico, que normalmente as gerações recebem de herança. $\mathrm{O}$ movimento de abandono do centro é forçado pelo Poder Público no Brasil, em geral. Na Itália e em várias partes da Europa o centro antigo e histórico é mantido para turismo e se constrói outra cidade nos arredores, de forma que se diminui a pressão para supressão dos edifícios antigos.

Assim, no Brasil, as ocupações urbanas mais burocratizadas seriam os centros históricos, que além de suportar os mesmos tipos de regulações impostas ao resto da cidade, só que mais estritas, ainda há limitações quanto às fachadas e demolições. O resultado disso é o caso do prédio neoclássico Matarazzo na esquina da Av. Paulista com Pamplona, construído em 1896 que no seu centenário foi demolido, após várias disputas midiáticas e judiciais contra uma prefeita coletivista. Mais um caso do indivíduo contra o Estado. Aliás, coletivismo e centralização, ao longo do tempo, tendem a promover uniformização das estruturas urbanas 
e das edificações, como em Brasília ou os conjuntos populares do tipo CDHU, Singapura, Minha Casa, Minha Vida etc.

\subsection{Culturais}

Em alguma medida a organização social de nossos ancestrais se reflete na organização atual, vejamos brevemente como eram, segundo Ribeiro (1995).

- Os índios, que acreditavam na natureza anímica, se organizavam em torno de uma grande oca central, com ocas menores ao redor, terreiros de agricultura rudimentar e rios próximos. As famílias viviam unidas, dormindo praticamente todos juntos em uma construção sem divisórias. Eram seminômades, com atividades de caça e coleta associadas a uma agricultura de subsistência. A organização espacial, portanto, era radial e pouco complexa, tendo a oca como centro e caminhos por terra e por água definidos.

- Os portugueses cristãos se agrupavam em vilas também próximas a rios, mas preferencialmente na beira mar, se organizavam em terrenos pequenos, ocupando aclives íngremes. A concentração de pequenas residências justapostas à via era uma estratégia de defesa, assim as famílias viviam cada uma em seu espaço, mas muito próximas. Nesse sentido são as servidões em Florianópolis, análogas às ruas estreitas dos centros de qualquer cidade histórica brasileira. De origem açoriana, o povo que primeiramente ocupou a ilha tratou de reproduzir seu local de origem, ocupando as encostas estáveis dos morros de granito e abrindo ruas extremamente íngremes e estreitas. Solução adequada à segurança, mas comprometedora para a expansão urbana.

- Já os africanos, acreditavam em dois mundos, um visível e o outro invisível, que interagiam entre si. Quando se organizavam em pequenas tribos eram nômades, caçadores e coletores, mas quando em agrupamentos maiores criavam gado, dominavam metalurgia, escrita e agricultura. Chegaram a formar grandes impérios. É forte o sentido de vida comunitária e de compartilhamento.

A brasilidade, herdando e modificando as características de seus povos originários, na luta para sobreviver em um clima tropical úmido, vai criando suas instituições de poder e controle, como o estamento burocrático (FAORO, 1979), que se compõe de inúmeras funções estatais, hierarquizadas e preenchidas por indivíduos. Cada um desses cargos se torna um espaço de poder, onde o burocrata passa a exercer um poder no seu domínio (que pode ser em área geográfica, alcance burocrático, financeiro etc.). De modo que as decisões resultantes do poder público sofrem a influência de todos os indivíduos que a compõe. Trata-se de algo análogo a uma soma vetorial em que cada vetor tem sua força e direção (em maior ou menor grau), cuja resultante decorre de todas as interferências individuais. É a microfísica do poder de Foucault (1979), que entende como átomos cada burocrata agindo no sistema individualmente, exercendo sua força. No Brasil esse processo se mescla ao patrimonialismo, como descrito por Faoro (1979), onde cada burocrata se acha dono daquele espaço de poder e o trata como um feudo do qual extrai recursos que os julga seus! Nisso também atua a cordialidade, descrito 
por Holanda (1936), que deseja transformar toda relação social em familiar, acabando com a formalidade e transformando instituições públicas em extensão da casa do burocrata.

Outro traço cultural brasileiro é a percepção do salvador da pátria. Análogo ao libertador latino-americano, esse ente fictício presente na nossa cultura nos coloca em posição passiva diante da realidade, a aguardar um milagre a ser realizado por alguém com dons e características especiais, já que o indivíduo em sua pequenez é incapacitado para reagir, lutar e mudar sua própria realidade. Esse ente por vezes é atribuído também ao próprio governo. Se espera que a prefeitura faça alguma coisa, ou que os políticos olhem para o problema. Esse aspecto cultural é terreno propício para o surgimento de populistas, sejam políticos ou gente como Pablo Escobar e Maradona.

Nesse caldeirão, os problemas que surgem nas cidades têm suas soluções politizadas e burocratizadas, onde políticos resolvem um problema ou até mesmo os criam, na medida em que tem uma oportunidade para um ganho objetivo, seja econômico, político ou de poder, que, portanto, está desvinculado do interesse do cidadão comum. Como os populistas que necessitam da pobreza para se justificar, a ação dos políticos responde à pergunta: o que eu ganho com isso?

Envolvidos na elaboração do Plano Diretor, os burocratas municipais são teóricos que passaram em concursos públicos, reproduzindo o que aprenderam na faculdade, que normalmente se tratam de teorias urbanas ultrapassadas e/ou carregadas de ideologia e afeitas a um planejamento central. Esses, como todos os profissionais formados por grandes universidades brasileiras, sofrem do mesmo problema: descolamento da realidade.

Em um Plano Diretor é comum encontrar politizações de problemas, discurso identitário, coletivismo e toda uma sorte de questões contemporâneas que nada tem a ver com urbanismo, tornando-o uma peça de propaganda política e de agendas ideológicas, novamente descoladas da natureza humana.

Além do descolamento com a realidade e natureza humana, há ainda outro problema: políticos e burocratas não sofrem diretamente punições por seus erros, o que para Descartes seria o bastante para não lhes dar crédito.

Para Aristóteles, que como bom grego antigo tinha uma visão coletivista, o melhor modelo de organização social é aquele em que se oferece condições para o indivíduo desenvolver seu potencial inato e, consequentemente, oferecer o melhor de si para a sociedade. Portanto, mesmo numa visão coletivista, o melhor é a liberdade individual.

O indivíduo que tem a oportunidade de buscar o desenvolvimento de seu potencial é o que também gera menor prejuízo à sociedade, ficando menos doente, se envolvendo em menos conflitos. Assim também uma área urbana bem planejada, com grandes eixos estruturantes, em acordo com suas potencialidades regionais e que não sofra com especulações dos ciclos econômicos, evita problemas e prejuízos diversos à sociedade. Planejamento estratégico se traduz em eficiência urbana (economia de combustível, menor índice de acidentes, maior velocidade de deslocamento, serviços urbanos mais acessíveis etc.) que naturalmente gera ocupação e valorização dos lotes. 
Então, as invasões são espaços cobiçados pelos cidadãos na informalidade, mas onde o desenvolvimento pessoal e a eficiência urbana podem ser comprometidos, haja vista a limitação do oferecimento de serviços públicos ou privados, o florescimento de atividades violentas com o crescimento de máfias e milícias, comércio de produtos de furto etc., que usam a informalidade para se ocultar e viabilizar seu negócio. $\mathrm{O}$ pior dessa prática se manifesta na consolidação de milícias que, sob a pretensa hipótese de proteção (a mesma que o serviço estatal diz promover) acabam explorando os moradores da região. Portanto, na atualidade com o sistema vigente sob a égide estatal, o cidadão comum é formalmente expropriado pelos impostos e, além disso, na informalidade extorquido pelas milícias.

Com relação às áreas verdes urbanas, há destinação de espaços para praças, parques, corredores ao longo das drenagens, bosques, hortos florestais etc. Na prática há o risco de invasões dessas áreas e o político surge para regularizar a invasão! O comportamento populista alimenta a prática da invasão e se retroalimenta dos votos dos invasores. O mesmo comportamento ocorre em grandes vias, especialmente aquelas que são executadas apenas em parte, deixando uma parte livre para expansão, mas que acaba invadida por moradores. A possibilidade de aumentar o lote, a falta de visão de conjunto, a oportunidade de ganho imediato (alta preferência temporal) e a ajuda de políticos para regularizar a situação, incentivam moradores locais a invadir a via.

A invasão de praças, áreas verdes e grandes avenidas vai afastando a área urbana de um aspecto natural, com paisagens verdes e de ampla visão, tornando a cidade um lugar estranho, agressivo e não acolhedor. Interessa ao cidadão comum levar a estética urbana a níveis cada vez mais elevados, como desejava Hegel (2001), concretizar a natureza e o espírito humano no mundo. Já para Scruton (2013), reduzir o uso dos espaços à mera ideia de eficiência, leva a perda da beleza e a posterior subutilização dos mesmos. Portanto não basta ser eficiente, a área urbana há que ser bela, refletindo a natureza e elevando o espírito humano. Glaeser (2011) também observa que, mesmo com todas as dificuldades, a era urbana não acabará tão cedo e que a grande revolução urbana foi proporcionar aos seres humanos um espaço mais rico, belo, saudável e feliz.

\subsection{Físicas}

O indivíduo ao empreender uma ocupação ou construção enfrenta uma dualidade. Como ser humano, tem a tendência de fazer as coisas à sua maneira, projetar seu caráter e valores no mundo, mas para isso se depara com suas condições financeiras e limitações físicas do ambiente.

Portanto primeiro vem uma análise da viabilidade (que envolve economia, segurança, meio físico etc.) e só depois vem a ação humana, baseada em estratégia. Esse processo de tomada de decisão é tão mais eficiente quanto mais se aproxima do nível individual.

São os indivíduos, com suas redes de relacionamento, que possuem a maior quantidade de informação para analisar a viabilidade de empreendimentos urbanísticos, levando em consideração inclusive aspectos do meio físico. Em outras palavras, o maior conhecedor de suas terras é o proprietário. 
Serras, rios, penhascos e outros acidentes naturais são vistos como obstáculos para o crescimento urbano dentro da ótica do urbanismo tradicional, mas nunca o foram para a criatividade humana. Assim quanto mais liberdade ao empreendedor, mais soluções para esses obstáculos. A experiência mostra que quando há liberdade, o problema se torna em oportunidade para a genialidade humana.

A geopolítica também não considera as limitações físicas como um problema. Para Mackinder (1904) o poder está centrado no domínio terrestre, portanto estradas, pontes, relações de comércio, fundação de distritos satélites, ocupação de terras por agricultura, ocupação de entradas/saídas de vales e cânions entre outras, são ações estratégicas para consolidação de poder e influência. Associa-se essa ideia ao conceito de polo regional, como mapeado por IBGE (2018). Quanto ao relevo, nos planos diretores via de regra se veda totalmente a ocupação formal em topos de morros e encostas íngremes. Mas informalmente a ocupação se dá, normalmente de forma desordenada e, com muito mais risco. Mas isso já vimos que interessa a políticos.

Já Mahan (1965) considera que um império necessita dominar as águas para crescer, então deve fortalecer a marinha de cabotagem, protegida pela de guerra, estabelecendo rotas de comércio mundial, dominar estreitos e ilhas, ocupar o litoral e as margens dos grandes rios construindo portos e instalações navais. Quanto às águas, a legislação veda o uso comercial e burocratiza o individual para portos, criando mais um monopólio/oligopólio artificial. O cruzamento de grandes rios ainda é feito por balsas, que são concessões estatais. Em Manaus surgiu o conceito de flutuantes de aluguel, uma estrutura como uma casa com todos os serviços, que até o momento atuam análogas às chácaras de fim de semana, até algum político decidir legislar sobre essa iniciativa, criando regulações, taxas e multas.

O entendimento é que impérios (aqui podem ser entendidos tão somente como cidades, condomínios ou até ao nível individual), devem considerar o fortalecimento de infraestrutura e conexões tanto terrestres quanto por água. Mas cada regulação imposta por burocratas e políticos é um desincentivo a esse fortalecimento.

Com relação às invasões e ocupações informais, elas serão mais bem sucedidas a depender das condições naturais do meio físico, como (1) disponibilidade de água em superfície (rios) ou subsuperfície (poços) para abastecimento, recreação e até pesca; (2) espessura, tipo de material, resistência e capacidade de infiltração de solos/rocha para assentar fundações, abrir vias, tratar e destinar esgotos; (3) relevo que permita escoamento de água, mas não seja tão íngreme que dificulte os acessos ou apresente risco de desmoronamento; (4) clima com chuvas e temperaturas moderadas, enquanto regiões com climas extremos do tipo desértico ou polar são limitantes.

\section{O Que Se Pode Esperar}

Dentro do atual paradigma há legislações que permitem ao menos diminuir a tributação, mas nunca as regulações, burocracia e fiscalização.

Para zonas industriais são elas: 
- ZPE - Zonas de Processamento e Exportação, criadas em 1988 e atualizada pela Lei no 11.508/2007, cuja regulamentação veio pelos Decretos nº 6.634/2008 e no 6.814/2009, que dispõe sobre o regime tributário, cambial e administrativo. As ZPE são áreas de livre comércio com o exterior, destinadas à instalação de empresas com produção voltada à exportação. Para efeito de controle aduaneiro, as ZPE são consideradas zonas primárias, ou seja, diretamente associadas a portos ou aeroportos. Estão isentas de IPI, Cofins, PIS/ Pasep, Imposto de Importação e do AFRMM. Há casos de planejamento e instalação de ZPE fracassados por todo o país.

- ZF - Zonas Francas são também áreas para produção e circulação de bens com incentivos fiscais como isenção do IPI, do Imposto de Importação e de Exportação, isenção temporária do IPTU e desconto no ICMS. Um caso de sucesso relativo é a Zona Franca de Manaus (Decreto-Lei no 288, de 28 de fevereiro de 1967), que compreende áreas de livre comércio por toda a Amazônia ocidental e Amapá, apesar da única a prosperar ser a de Manaus.

Condomínios industriais públicos - são áreas normalmente destinadas por prefeituras com vantagens para instalação de indústrias, que vão desde cessão da área com infraestrutura básica, isenção de IPTU e ISS. Pelo fato do planejamento central, apresenta ineficiência na localização (desconsiderando fluxos de pessoas e mercadorias) e infraestrutura (vias insuficientes, rede de energia inadequada, falta de água e de tratamento de efluentes etc.).

Condomínios industriais privados - são áreas que já obedecem a incentivos de mercado, então melhor localizadas e com infraestrutura confiável, mas onde recaem todos os impostos. As vantagens aqui seriam dividir custos fixos (segurança, manutenção, acessos etc.) e posicionarse em um cluster empresarial.

Já para as zonas residenciais:

Condomínios residenciais privados, cada vez mais autônomos, que constroem e mantêm infraestrutura local (acessos, vias, água, esgoto, energia, lixo, segurança, comunicação etc.). Pelo princípio de descentralização, os condomínios privados garantem maior eficiência no oferecimento de serviços, manutenção e na solução de problemas internos. Há exemplos de condomínios privados horizontais e verticais, desde alto padrão, até os mais econômicos. São casos de sucesso na instalação de pessoas e negócios, baseado em contratos privados. O desafio seria transformar os condomínios privados em áreas rivais e excludentes.

Condomínios residenciais públicos (construídos e/ou financiados pelo Estado), há também a vantagem da descentralização na sua manutenção e operação, mas todas as decisões de localização, dimensões, projeto, construção e destinação aos moradores (normalmente por sorteio ou enquadramento em um perfil socioeconômico) foram do tipo centralizada. Ainda, como não há deslocamento voluntário dos moradores, surgem venda e aluguel ilegal dos imóveis, falta de pagamento de condomínio, confusões frequentes e toda uma sorte de atividades ilícitas. Além de corrupção desde a concepção do projeto até a destinação das unidades, vícios construtivos, instalação de milícias e facções, execuções, calote, atividades ilícitas, som alto dia e noite etc. Socializado via impostos, o alto custo de um condomínio desse tipo deve-se à aquisição de terras, projeto e construção, além da burocracia e corrupção inerentes ao processo. 
Condomínios residenciais privados, apresentam baixo custo de oportunidade, alcançam terrenos baratos, estão abertos à inovação de formas, materiais e técnicas, oferecem segurança, dispõe de regras de vivência, governança e fiscalização próprias. Mas, para que sejam viáveis para todas as camadas da sociedade necessitam desregulamentação, desburocratização e descentralização.

E, para zonas comerciais ou mistas:

Condomínios comerciais/empresariais horizontais ou verticais evoluiriam para mistos, como Atlantic Station (Atlanta/EUA). Os verticais normalmente abrigam residências na parte superior dos edifícios, negócios na parte intermediária e comércios na parte inferior. Já os horizontais unem empresas, comércios, negócios, serviços, lazer, esportes e residências em uma mesma estrutura. Já há muito conhecidos na China e em vários lugares no mundo, até o momento são proibidos no Brasil. Barueri é a cidade onde mais se avançou nesse aspecto. É quando se necessita uma mudança de paradigma.

Então, dentro de um novo paradigma, surge o conceito de cidades privadas (https:// www.freeprivatecities.com/pt/), que poderia ser considerada uma evolução das atuais charter cities americanas como Reston (Virginia/EUA) e Irvine (California/EUA), ou um avanço na governança das mundialmente conhecidas Hong Kong, Cingapura, Dubai e Gurugram (Índia). Atualmente há iniciativas de cidades privadas em desenvolvimento na Nicarágua e Honduras (Próspera). Em outro patamar, mas ainda dentro da mesma lógica, estariam as nações privadas como Liberland, que seria uma evolução de Estados como Mônaco, Liechtenstein e Andorra.

Nesses espaços se estabelece um regime de leis e governança privados, onde o sistema de segurança, de justiça e de uso da infraestrutura comum fazem parte de um contrato de adesão. Propriedade privada e vida são os pilares dessas organizações. Colocando os incentivos nos lugares corretos, o pagador de impostos se transforma em cliente e tem possibilidade contratual de penalizar má gestão, corrupção e ineficiência! Quem, nesse sistema, oferece um mal serviço tende a ser banido pelo mercado, que desburocratizado e regido por leis naturais (e, portanto, universais) é dinâmico, desregulamentado e livre de monopólios/oligopólios artificiais.

Na esteira das cidades privadas, pode-se pensar na evolução dos próprios condomínios privados que, livres para empreender e gerar soluções de infraestrutura e governança aos usuários/moradores, tenderia a aumentar a eficiência de todo o processo, gerando oportunidades diversificadas a menor custo. Com relação aos eixos estruturantes, os empreendedores têm incentivos para propor vias que viabilizem negócios, que tendem a ser tanto maiores e mais interligados quanto forem as próprias vias!

Obviamente empreendedores farão Planos Diretores de seus empreendimentos, que podem vir a assumir outros nomes, mas que estariam submetidos a leis de mercado e teriam como foco o cliente-morador.

\section{Conclusões}

Os autores não desejam fazer um juízo de valor sobre o Plano Diretor. Não cabe aqui dizer se ele é bom ou ruim. Obviamente há casos de planos diretores que produziram 
avanços e organização urbana saudável, traçaram grandes avenidas, planejaram clusters de desenvolvimento e nós logísticos, mas com as informações disponíveis até o momento se pode concluir que o plano diretor como é feito hoje no Brasil não responde a incentivos de mercado, nem na elaboração, nem na sua gestão. Além disso se torna mais uma peça dentro da burocracia estatal, criando uma série de entraves, regulamentações, limitações, taxas, vistorias, multas e licenças.

Do observado, conclui-se que o modelo de desenvolvimento urbano vigente no Brasil não contempla planejamento estratégico, que acaba resultando no fracasso diante dos principais problemas das cidades. Excesso de intervenção estatal, planejamento central focado em ideologias, burocracia e regulamentação resultam em monopólios/oligopólios no oferecimento de serviços urbanos, áreas que sucumbem à tragédia dos comuns, ineficiência e aumento de custo, culminando em pobreza, abandono e insalubridade. A solução dos problemas urbanos necessita de outra visão, outro modelo, deve passar por uma mudança de paradigma!

$\mathrm{O}$ ato de pensar a cidade, como previsão de demanda futura e planejamento estratégico, que hoje cabe ao poder público, não segue a incentivos de mercado e sequer faz parte do rol de preocupações do governo. $\mathrm{O}$ setor de urbanismo das prefeituras praticamente se tornou um cartório que vai regularizando as áreas invadidas ao longo do tempo. Após o cidadão comum dispender tempo, pagar taxas, enfrentar burocracia, filas e sofrimento, concedem-no o direito de pagar IPTU. Se a escritura de um lote é o serviço estatal de reconhecimento de propriedade privada, então passa por todas as dificuldades de qualquer outro serviço estatal: carência artificial, monopólio (secretaria de urbanismo) e concessões estatais (cartórios), burocracia, taxas, ineficiência e fiscalização.

Quanto à operação dos serviços urbanos, o poder público sequer atende à demanda atual. São registros por problemas no abastecimento de água, coleta/tratamento de esgoto, transporte, energia, segurança, justiça etc. A melhora que se observou nas comunicações deveuse à abertura do mercado, que apesar de pequena, já possibilitou uma expansão nos serviços.

Se observa um esforço atual, ainda que acanhado, no sentido de mais liberdade para empreendimento nas áreas de saneamento, ferrovias, portos/hidrovias e loteamentos/ condomínios. Ao diminuir os entraves, se espera permitir a entrada de mais players nessas áreas, que resultaria em melhores serviços a menor custo.

Os vazios urbanos são tidos como um problema. Segundo burocratas, a expansão encarece os serviços, então defendem o adensamento da área urbana por eles delimitada. Nesse paradigma, aumentar a área urbana é um problema, mas se o paradigma mudar para o de condomínios privados, deixa de existir a figura Estatal provedora de serviços urbanos e deixa de fazer sentido qualquer regulamentação quanto a área urbana. Por outro lado, os lotes "vazios" formam um estoque futuro de áreas disponíveis para empreendimentos variados que podem manter a dinâmica da área urbana atual ativa. Desregulamentação dos centros históricos ou orientação a incentivos de mercado, como o caso do Bondinho de Santos/SP, podem reativar áreas abandonadas.

Limitações burocráticas (taxas, licenças, métricas etc) resultam no encarecimento do metro quadrado formal. A lei de mercado mostra que áreas se valorizam ao se consolidar 
com infraestrutura, então se justificam como investimento, por outro lado, quanto menor número de terrenos disponíveis, maior seu valor. Então para oferecer lotes com infraestrutura urbana no atual paradigma, o empreendedor necessita dispender tempo e recursos para atender a regulamentações burocráticas que retardam e encarecem o processo, culminando em oligopólios artificiais.

Em várias grandes cidades brasileiras verifica-se que, a partir da década de 1990, indústrias estão buscando se instalar em municípios menores. Burocratas e políticos se perguntam quais medidas poderiam ser tomadas para atrair essas empresas. Talvez, a pergunta esteja errada e seja o excesso de medidas que as atrapalhe. Então a solução que se propõe é no sentido de menos Estado, liberando o empreendedor, mesmo porque as soluções de mais Estado, já amplamente testadas no Brasil, não resolveram o problema.

No atual paradigma urbanístico brasileiro imperam ações do tipo mais estado. Acreditam que com mais planos, mais ações, mais diretrizes, mais fiscalização, mais obras e espaços públicos a cidade vai melhorar. Essa visão idealizada de planejamento central tem levado à situação que se conhece das cidades brasileiras: barreiras para executar qualquer tipo de projeto legalmente, que acabam sendo incentivos para ilegalidade, levando as pessoas a construir na periferia, longe da fiscalização do poder público, que neste caso, assume uma função castradora da livre iniciativa, provocando inclusive fuga de ideias e mentes. A burocracia funciona como um incentivo perverso contra empreendimentos viáveis, sustentáveis e belos, mas sucumbe a invasões e favelização, que muitas vezes inviabilizam grandes áreas, poluindo solo e água, desestabilizando encostas, impedindo acessos etc.

$\mathrm{Na}$ esteira dos incentivos trocados e recursos mal alocados, Cunha e Neves (2008) identificaram que, no caso dos Planos Diretores, são lacunas: planejamento de longo prazo, gestão estratégica, responsabilidade por resultados, participação popular e monitoramento/ avaliação. Mas atribui esses problemas a baixa escolaridade e ausência de consciência política. Se há relação com escolaridade, então seria observável regiões mais escolarizadas com Planos Diretores mais voltados a estratégia e, portanto, melhores resultados, o que não ocorre. Quanto à consciência política é difícil mensurar pela falta de definição.

Muitas cidades evoluíram a percepção de que a elaboração do Plano Diretor deve ser participativa, então criaram audiências públicas com participação popular e conselhos municipais e estaduais (conhecidos como ConCidades e regulamentados pelo Decreto 5.790/2006). A pergunta é: quem participa dessas audiências? Faz lembrar os consejos comunales na Venezuela, identificados por Lovera (2008) como apenas uma estratégia para criação de mais regulação onde delegados de partidos e/ou de políticos fazem maioria e aprovam leis que os beneficiem e/ou prejudiquem seus adversários.

Da experiência de consolidação de ocupações urbanas informais no Brasil pode-se concluir que a livre iniciativa dos indivíduos e suas famílias é exitosa em dividir lotes, pavimentar ruas, gerar infraestrutura e serviços, mas falha no desenho de traçado das vias. É um caso de sucesso na apropriação de propriedade privada, seja por primeira posse ou pela livre negociação da mesma com suas respectivas benfeitorias. Disso depreende-se que, no atual 
paradigma, o planejamento centralizado deveria focar no traçado das vias, garantindo sua linearidade, continuidade, dimensões e conexões.

Os efeitos deletérios de uma urbe mal ou não planejada são bem conhecidos: dificuldade de deslocamento, infraestrutura cara, confusão, informalidade. Mas há outro aspecto que é a concepção da realidade! Se, cada indivíduo tende a reproduzir as experiências da infância na idade adulta, o que se pode esperar de crianças que crescem em ambientes desorganizados, confusos, congestionados, apertados, sujos, enfim precários do ponto de vista estético, que comprometem a eficiência em termos financeiros, funcionais e de segurança, enfim um ambiente em funcionamento ineficiente, feio, caro e inseguro?

Apesar de toda ineficiência e descolamento com a realidade, há pressões para aumentar o controle estatal sobre as áreas urbanas, seja por aspectos burocráticos/legais devido a necessidade de levar serviços públicos de qualidade a áreas cada vez mais distantes, seja por aspectos culturais como medo da expansão urbana, ou ambientais com a justificativa das mudanças climáticas (ESPÍNDOLA; RIBEIRO, 2020). Portanto não se espera que a intervenção estatal nas cidades irá diminuir.

Mas nota-se que o poder público está perdendo seu lugar na sociedade. As pessoas, na informalidade, vão ocupando os espaços, expandindo a área urbana, organizando-se em comunidades e criando infraestrutura. Outro lado ruim é que afastam as grandes empresas e muitas das oportunidades de enriquecimento com elas.

A desburocratização e desregulamentação das ações no desenvolvimento urbano pode não impedir casos malsucedidos, experiências ruins e prejuízo, mas viabilizará uma infinidade de projetos bem-sucedidos que virão a ser os modelos de desenvolvimento futuro, trazendo inovação, prosperidade, bem-estar, beleza, felicidade e prosperidade para o ambiente urbano.

\section{Referências}

ANGEL, S.; LAMSON-HALL, P.; BLANCO, Z. G. Anatomy of density: measurable factors that constitute urban density. Buildings and Cities, v. 2, n. 1, p. 264-282, 2021.

ARISTÓTELES. Metafísica; Ética a Nicômaco; Poética. São Paulo: Abril Cultural, 1979.

BASTIAT, F. The Law. Auburn: Ludwig von Mises Institute, 2007 [1850].

BECKER, M.C. Managing Dispersed Knowledge: organizational problems, managerial strategies and their effectiveness. Journal of Management Studies, v. 38, n. 7, 2002.

BERTAUD, A. Brasilia spatial structure: Between the Cult of Design and Markets. Brasília: Metropolitana 2050/ Preservação e Desenvolvimento, 2010.

BERTAUD, A. The costs of Utopia: Brasilia, Johannesburg, and Moscow. Dossiê Brasil-África do Sul Paranoá, n. 18, 2017.

CUNHA, S.R.P.; NEVES, A. J. A experiência de Rondônia em planejamento. Saber científico, Porto Velho, v. 1, n. 2, p. 156 - 177, jul./dez., 2008.

DESCARTES, R. Discurso do Método. São Paulo: Martins Fontes, 1996. 
ERDMANN, K.; FURTH, S.; HAMILTON, E. The Link Between Local Zoning Policy and Housing Affordability in America's Cities. Mercatus Center, 2019. George Mason University. Disponível em: www.mercatus.org. Acesso em: 15 mai 2004.

ESPÍNDOLA, I.B.; RIBEIRO, W.C. Cidades e mudanças climáticas: desafios para os planos diretores municipais brasileiros. Cadernos Metrópole, São Paulo, v. 22, n. 48, p. 365-395, 2020.

EVANS, G.W. et al. The American Economic Review, v. 88, n. 3. p. 495-515, 1998.

FAORO, R. Os donos do poder: formação do patronato político brasileiro. Porto Alegre: Globo, 1979.

FOUCAULT, M. Microfísica do poder. Rio de Janeiro: Edições Graal, 1979.

FRIEDMAN, M. Entrevista a Asman, D. Fox News. Disponível em: http://www.foxnews.com/story/0,2933,230045,00. html. Acesso em: 15 mai 2004.

GLAESER, E. Triumph of the City: How Our Best Invention Makes us Richer, Smarter, Greener, Healthier, and Happier. New York: Penguin Press, 2011.

GLAESER, E.L.; GYOURKO, J. The Impact of Building Restrictions on Housing Affordability. FRBNY Economic Policy Review, v.?, n.?, p. 21-39, 2003.

GREY, M; MCBIRNEY, J. Liberalizing Land Use Regulations: The Case of Houston. Mercatus Center, 2020. George Mason University. Disponível em: www.mercatus.org. Acesso em: 15 mai 2004.

GREY, M. N. The Bootlegger and Baptist Coalition to Restrict Urban Growth. The American Conservative. Mercatus Center. Fairfax: George Mason University, 2021.

HAYEK, F. Direito, Legislação e Liberdade: Uma formulação dos princípios liberais de justiça e economia política. A Ordem de um Povo Livre. São Paulo: Ed. Visão, 1985.

HAYEK, F. Os Erros Fatais do Socialismo. São Paulo, Faro Editorial, 2017.

HAYEK, F.A. Monetary Theory and the Trade Cycle. USA: Sentry Press, 1933.

HEGEL, G.W. Cursos de estética. São Paulo: Edusp, 2001.

HOLANDA, S. B.de. Raízes do Brasil. São Paulo: Companhia das Letras, 1995.

IBGE - Instituto Brasileiro de Geografia e Estatística. Diretoria de geociências. Região de Influência das Cidades. Mapa 1:5.000.000. Brasil, 2018.

IKEDA, S. China's "Planned Capitalism" Kills Wealth: Prosperity Depends on What We Want to Buy. FEE - Foundation for Economic Education, 2016. Disponível em: https://fee.org/articles/chinas-planned-capitalismkills-wealth/. Acesso em: 15 mai 2004.

IKEDA, S. Shut Out: How Land-Use Regulations Hurt the Poor. Economics paints a damning picture of zoning and smart growth. FEE - Foundation for Economic Education, 2015. https://fee.org/articles/shut-out-how-landuse-regulations-hurt-the-poor/.Acesso em: 15 mai 2004.

JACOBS, J. The Death and Life of Great American Cities. NY: Random House, 1961.

KOLKO, G. Railroads and Regulation: 1877-1916. Princeton: Princeton Legacy Library, 1965.

LAMBERT, J. Os Dois Brasis. Rio de Janeiro: Brasiliana, 1967.

LEÔNCIO, V. Patria Amada. Belo Horizonte: editora 41, 2014. 
LEVINSON, D.; KING, D. Transport Access Manual: A guide for Measuring Connection Between People and Places. Sydney: CTAM - Committee of the Transport Access Manual, 2020.

LING, A. Guia de Gestão Urbana. São Paulo: ArqFuturo/BEI, 2017.

LOVERA, A. Los consejos comunales en Venezuela: ¿Democracia participativa o delegativa?. Revista Venezolana de Economía y Ciencias Sociales, Caracas, v. 14, n. 1, 2008.

MACKINDER, H.J. The Geographical Pivot of History. Geographical Journal, v. 23, p. 421-437, 1904.

MAHAN, A.T. The Influence of Sea Power upon History: 1660-1783. London: Methuen \& Co, 1965.

MILL, J. S. Princípios de Economia Política: Com algumas de suas aplicações à filosofia social. São Paulo: Editora Nova Cultural Ltda, 1996 [1848].

MINKLER, A. P. The problem with dispersed knowledge: firms in theory and practice. Acesso em: 15 mai 2004.

MISES, L. V. Ação Humana: Um Tratado de Economia. Auburn: Instituto Mises Brasil, 2010 [1949].

RIBEIRO, D. O Povo Brasileiro: a formação e o sentido do Brasil. São Paulo: Companhia das Letras, 1995.

ROBES, T. Leviatã ou Matéria: Forma e Poder de um Governo Eclesiástico e Civil. São Paulo: Martins Fontes 2014 [1651].

SANTOS, M. Por uma Geografia Nova. São Paulo: Hucitec, 1978.

SCHLICKMANN, M. P. Acessibilidade como métrica de gestão da mobilidade. https://caosplanejado.com/ acessibilidade-como-metrica-de-gestao-da-mobilidade/. 2021. Acesso em: 15 mai 2004.

SCRUTON, R. Beleza. São Paulo: É Realizações. 2013.

SIERGAN, B.H. Land Use Without Zoning. Lanham: Rowman \& Littlefield Publishers, 1972.

SILVA, J. da C.; SANTOS, W.S.C. dos; SILVA, A.de A. Planejamento e Plano Diretor de Porto Velho. Revista da ANPEGE, v. 7, n. 8, p. 81-92, ago./dez, 2011.

ZMITROWICZ, W; NETO, G.de A. Infraestrutura Urbana. São Paulo: EPUSP, 1997.

ZMITROWICZ, W.; BORGHETTI, G. Avenidas 1950-2000: 50 anos de planejamento da cidade de São Paulo. São Paulo: Edusp, 2009.

RECEBIDO EM: 29 DE MARÇO DE 2021.

ACEITO EM: 05 DE JULHO DE 2021. 